\title{
Možnosti využití starých topografických map z let 1763-1768 pro hodnocení vývoje vodních ploch a potenciál jejich obnovy
}

\author{
MAREK HAVLÍČEK, HANA SKOKANOVÁ, VÁCLAV DAVID, RENATA PAVELKOVÁ, \\ ALEŠ LÉTAL, JINDŘICH FRAJER, PATRIK NETOPIL, BOŘIVOJ ŠARAPATKA
}

Klíčová slova: vodní plochy - staré topografické mapy - povodí - Česká republika

\section{SOUHRN}

Potenciál obnovy vodních ploch je aktuálním tématem v současném krajinném plánování. Nejčastěji jsou na území České republiky zkoumány vodní plochy na starých topografických mapách od poloviny 19. století, na kterých je již velmi dobrá polohová přesnost topografického zákresu. Přesto můžeme také použít starší mapování, konkrétně první rakouské vojenské mapování z let 1763-1768, které nám umožňuje nalézt hráze vodních ploch a posoudit možnosti obnovy zaniklých vodních ploch. Na základě analýzy tří zájmových území (povodí Bystřice, Jevišovky a Opavy) bylo zjištěno, že největší potenciál obnovy vodních ploch z let 1763-1768 byl zaznamenán v povodí řeky Jevišovky. $V$ tomto povodí byla u 51 \% zaniklých vodních ploch evidována dochovaná hráz či její větší část. Ostatní dvě povodí vykazují menší potenciál pro obnovu zaniklých vodních ploch - to je $26 \%$ pro povodí řeky Opavy a $24 \%$ pro povodí řeky Bystřice.

\section{ÚVOD}

Mapy 1. rakouského vojenského mapování v měřítku $1: 28800$, které byly na našem území vytvořeny v letech 1763-1768, jsou cenným informačním zdrojem o rozsahu vodních ploch. Tyto mapy sice nedosahují polohopisné přesnosti navazujícího 2. rakouského vojenského mapování, ale i bez dostatečných geodetických základů je Ize využít pro interpretaci výskytu vodních ploch, lokalizaci hrází rybníků a zhodnocení přibližného rozsahu zátopového území [1, 2].

$\checkmark$ období druhé poloviny 18. století bylo na našem území značné množství rybníků, v Úředním soupisu rybníků (1786) bylo jen v Čechách zaznamenáno 20789 rybníků o celkové výměře 76816 ha [3]. I když se jednalo o období, ve kterém docházelo k postupnému úpadku rybníkářství a rušení rybníků, Ize očekávat, že ve většině povodí zachycují větší počet vodních ploch než na následujícím mapování z let 1836-1852 [1, 2]. V 18. a 19. století se na poklesu počtu vodních ploch podepsal vliv různých hybných sil - např. osvícenské reformy Josefa II., včetně patentu o zrušení nevolnictví z roku 1871 a vyvolaným „hladem po půdě", státem podporované inovace v zemědělském hospodaření, rozmach pěstování cukrové řepy, technické inovace spojené s jiným pohonem, než vodním kolem, rozmach železnice s požadavky na trasování v údolích vodních toků, špatný technický stav rybníků či obavy z šiření nemocí v okolí vodních ploch [1, 4-6].
Článek si klade za cíl zhodnotit na základě konkrétních prípadových studií možnosti využití starých topografických map z let 1763-1768 pro hodnocení vývoje vodních ploch a potenciál jejich obnovy. Obdobné články o historickém vývoji vodních ploch z různých povodí České republiky se zabývaly převážně vodními plochami z období let 1836-1852 a současností, prípadně z dalších doplňujících období topografického mapování v měřítku 1 : 28800 a $1: 25000$ z let 1876-1880, 1953-1957 a 1988-1995 [7-9]. V posledních letech se už také objevují práce, které využívají detailnějších map Stabilního katastru v měřítku 1:2880 a podrobných aktuálních modelů terénu vytvořených z leteckého laserového skenování území [10].

\section{ZÁJMOVÁ ÚZEMÍ}

Pro studium potenciálu obnovy vodních ploch evidovaných na mapách z let 1763-1768 byla vybrána povodí ze všech hlavních povodí v České republice, tedy povodí Dunaje, Odry a Labe. Z povodí Dunaje to bylo povodí Jevišovky, z povodí Odry šlo o povodí Opavy a v povodí Labe se jednalo o povodí Bystřice - viz obr. 1. Při výběru povodí bylo snahou postihnout různé př́rodní

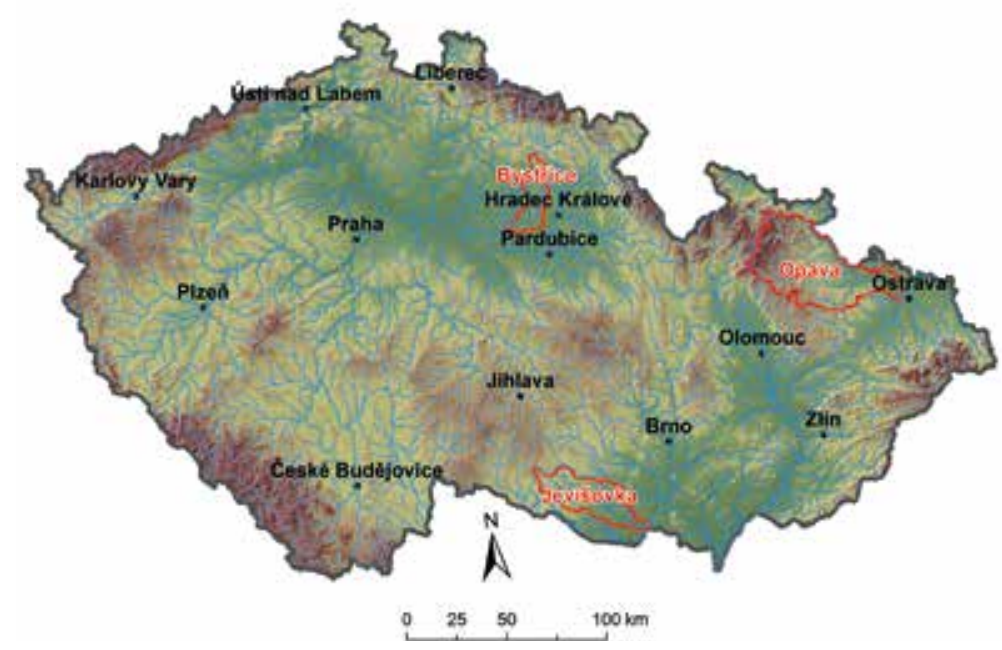

Obr. 1. Zájmová území povodí Opavy, Jevišovky a Bystřice

Fig. 1. Study areas - Opava river basin, Jevišovka river basin, Bystřice river basin 
poměry, různé socioekonomické podmínky, způsoby osídlení a zároveň zastoupení povodí z odlišných historických administrativních územích - zástupce z oblasti Čech, Moravy a Slezska.

Povodí Opavy je ze tří zkoumaných povodí největší, má celkovou rozlohu 2088 km². Také vykazuje nejvyšší relativní výškovou členitost, protože zdrojnice Opavy, tedy Bílá Opava a Střední Opava mají své prameny na svazích masivu Pradědu v Hrubém Jeseníku v nadmořské výšce 1280 m. Významným prítokem Opavy je i řeka Moravice pramenící jižně od Pradědu v nadmořské výšce 1134 m. Pramenné oblasti mají charakter hornatin nebo vrchovin a leží v geomorfologických celcích Hrubý Jeseník a Zlatohorská vrchovina [11]. Střední část toku protéká Nízkým Jeseníkem, dolní část toku Opavskou pahorkatinou. Soutok Opavy s Odrou se nachází v nadmořské výšce 207 m v Ostravě.

Z hlediska typologie krajiny je v povodí Opavy velmi pestré zastoupení rámcových krajinných typů podle reliéfu [12]. Převažuje krajina vrchovin Hercynica rozkládající se ve střední části povodí a jižních okrajových částech, velká zastoupení mají také krajiny plošin a pahorkatin, vyskytující se ve východní části povodí na Opavsku a Hlučínsku, se solidním potenciálem pro výskyt vodních ploch. Západní část území v Hrubém Jeseníku je tvořena krajinou výrazných svahů a skalnatých horských hřbetů a krajinou hornatin, kde se nedá predpokládat větší zastoupení vodních ploch. Naopak pro výskyt vodních ploch jsou vhodné krajiny širokých říčních niv v dolní části povodí Opavy a krajiny zaříznutých údolí v povodí řeky Moravice. V okolí Bruntálu Opavy se plošně vyskytují malé izolované kužely a sopečná území. V povodí Opavy se nacházejí různé typy sídelních krajin - staré sídelní krajiny Hercynica na Opavsku a Hlučínsku, krajiny vrcholně středověké kolonizace Hercynica ve střední části povodí, krajiny pozdní středověké kolonizace v okolí měst Vrbno pod Pradědem, Bruntál, Vítkov, krajiny novověké kolonizace Hercynica v oblasti Hrubého Jeseníku, vyšších částí Nízkého Jeseníku a sopečných kuželů. Četnější výskyt vodních ploch Ize predpokládat u starých sídelních krajin s vyšší hustotou sídel a obyvatelstva. Z hlediska využití krajiny v povodí Opavy prevažují lesozemědělské krajiny (ve střední části povodí), dále lesní krajiny (převážně na západě povodí) a nejmenši zastoupení mají zemědělské krajiny (ve východní části území v nižších nadmořských výškách).

Převážná část povodí Jevišovky se nachází v Jevišovické pahorkatině, dolní část povodí zasahuje do Dyjsko-svrateckého úvalu [4]. Od pramenné oblasti s nadmořskou výškou okolo $500 \mathrm{~m}$ n. m. rovnoměrně klesá nadmořská výška až po soutok s Dyjí ( $175 \mathrm{~m}$ n. m.). Celková plocha povodí činí $787 \mathrm{~km}^{2}$. V povodí Jevišovky se vyskytují čtyři typy rámcových krajinných typů podle reliéfu [12] V západní pramenné části území a na horním toku Jevišovky to je krajina vrchovin Hercynica, ve střední části povodí krajina plošin a pahorkatin, ve východní části krajina rovin, občas protnutá krajinou zařezaných údolí a v nejnižší části území až po soutok s Dyjí krajina širokých říčních niv. Většina území je z hlediska reliéfu vhodná pro budování vodních ploch. Větší část povodí Jevišovky patří do staré sídelní krajiny Pannonika (východně od Jevišovic), západní část území pak do krajiny vrcholně streedověké kolonizace Hercynica. Rámcové krajinné typy způsobů využití krajiny jsou v povodí Jevišovky reprezentovány převážně zemědělskou krajinou, částečně lesozemědělskou krajinou a lesní krajinou [12].

Povodí Bystřice se nachází převážně v pahorkatinném reliéfu s nadmořskou výškou 200 až 300 m, pouze pramenná oblast má charakter vrchoviny s nadmořskými výškami mezi 300 až 500 m n. m. Řeka pramení v Krkonošském podhưř́i, protéká Jičínskou pahorkatinou a do Cidliny se vlévá ve Východolabské tabuli v Chlumci nad Cidlinou [11]. Celková plocha povodí je 379 km².

$\checkmark$ povodí Bystřice se v pramenné oblasti vyskytují krajiny vrchovin Hercynica, na které navazují v jižní polovině území krajiny rovin [12]. Okrajově jsou zde zastoupeny i krajiny rozřezaných tabulí ( $v$ severní části povodí), krajiny plošin a pahorkatin (u Chýště) a krajiny širokých rríčních niv (v okolí řeky Bystřice mezi Kratonohy a Olešnicí). Z hlediska reliéfu je většina typů krajin v povodí Bystřice vhodná pro budování vodních ploch. Převážná část území povodí Bystřice patři mezi krajiny vrcholně středověké kolonizace Hercynica, severní pramenná oblast patří mezi krajiny pozdní středověké kolonizace Hercynica a naopak jižní část území mezi staré sídelní typy Hercynica. Z rámcových krajinných typů způsobů využití krajiny jsou nejvíce v povodí Bystřice zastoupeny zemědělské krajiny a lesozemědělské krajiny, podíl lesních krajin je velmi nízký, specifické je zastoupení rybničních krajin v okolí Obědovic a Písku.

\section{METODIKA}

Historický vývoj vodních ploch byl analyzován za použití vrstev prostorových objektů vytvořených vektorizací nad mapovými sadami starých topografických map v prostředí GIS. Vektorizace vodních ploch probíhala v prostředí Arc GIS metodou digitalizace z obrazovky [5]. Pokud byl uveden v mapě název objektu, tak byl doplněn do príslušné atributové položky. Vodní plochy byly zkoumány na podkladě mapových sad 1. rakouského vojenského mapování $1: 28800$ (1763-1768). Pro zjištění prípadné kontinuity jejich výskytu byly rovněž využity mapy 2. rakouského vojenského mapování 1 : 28800 (1836-1852), 3. rakouské vojenské mapování 1 : 25000 (1876-1880), československé vojenské topografické mapy 1: 25000 (1953-1957), československé vojenské topografické mapy 1 : 25000 (1988-1995) a základní mapy ČR (ZABAGED) 1 : 10000 z let 2014-2015. Pro hodnocení vývoje vodních ploch byly zkoumány všechny vodní plochy zaznamenané na topografických mapách, které pak byly dále interpretovány podle velikosti a struktury typů vodních ploch. Použití I. rakouského vojenského mapování bylo vzhledem k topologickým nedostatkům tohoto kartografického díla upraveno detailním metodickým postupem. Nejdř́ve byly

Tabulka 1. Počet a rozloha vodnich ploch v povodí Opavy v letech 1763-2015

Table 1. Number and area of water bodies in Opava river basin (1763-2015)

do 1,0 ha $\quad 1,0-4,9$ ha $\quad 5,0-9,9$ ha 10,0 ha a více Počet celkem Výměra celkem (ha)

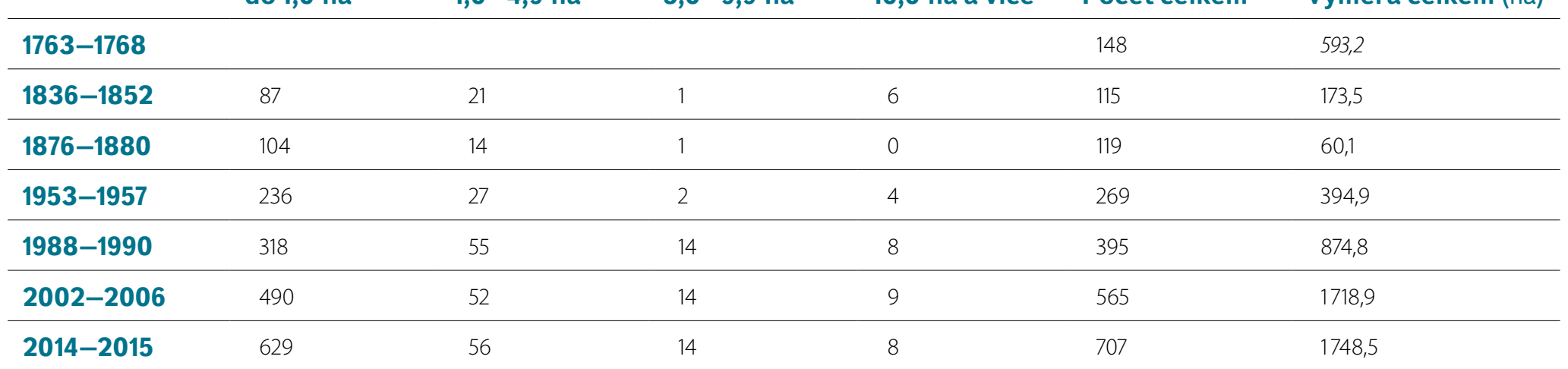




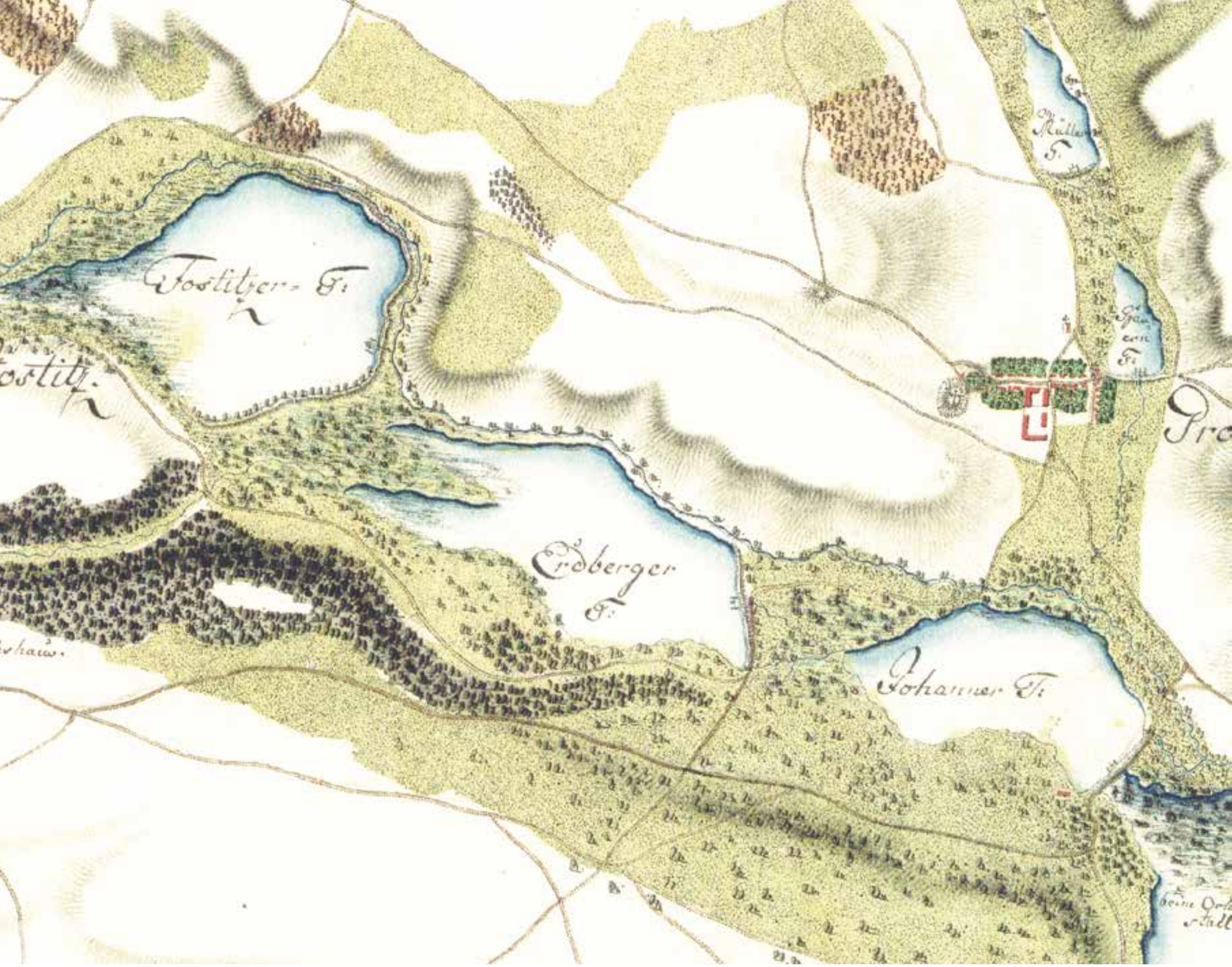

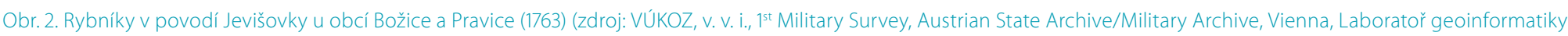
Univerzita J. E. Purkyně)

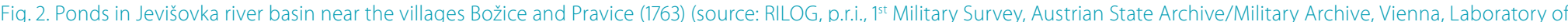
Geoinformatics University of J. E. Purkyně)

lokalizovány vodní plochy bodově (ideálně na místa hrází rybníkủ či do středu vodních ploch). V prípadě větších vodních ploch byla provedena rekonstrukce rozlohy vodní plochy s cílem získat orientační výměry vodních ploch v povodí v období let 1763-1768.

Při rekonstrukci vodních ploch v GIS byl využit podrobný model území reliéfu České republiky 4. generace (DMR 4G) z ČÚZK. V prípadě zachování hráze nebo části hráze byl rozsah zátopového území rybníka odvozen od nadmořské výšky hráze, sníženou na výšku maximální hladiny vodní nádrže. Průměrně byl řešen odpočet $0,5 \mathrm{~m}$ nadmořské výšky, přičemž obecně nejvyšší hodnota převýšení koruny hráze nad maximální hladinu je u malých vodních nádrží navrhována na 0,6 m.
Pro potenciál obnovy vodních ploch z období let 1763-1768 je považována za zásadní informace o aktuálním stavu hráze a využití zátopového území. Stav hráze byl interpretován následně těmito kódy v atributové tabulce:

0 - neřešeno - rybník stále existuje,

1 - $v$ terénu je $v$ současné době patrná velká část hráze,

2 - v terénu je v současné době patrná velká část hráze a vede po ní zpevněná komunikace (asfaltová, betonová, panelová),

3 - v terénu je v současné době patrná velká část hráze a vede po ní nezpevněná komunikace (vč. štěrkových cest),

4 - v terénu je v současnosti patrná menší část hráze,

5 - v terénu jsou v současnosti stopy existence bývalé hráze,

6 - žádné stopy hráze nejsou v současnosti v terénu patrné. 


\section{VÝSLEDKY A DISKUSE}

\section{Povodí Opavy}

V letech 1763-1768 bylo v povodí Opavy evidováno celkem 148 vodních ploch s približnou výměrou 593 ha. V letech 1836-1852 poklesl počet vodních ploch v povodí Opavy na 115 (tabulka 1), tento pokles byl doprovázen významným poklesem celkové výměry vodních ploch v povodí Opavy (na 174 ha). Bylo zde ještě zachováno šest vodních ploch o výměře větší než 10 ha, ale převažovaly spíše menší vodní plochy do 1 ha, prípadně od 1 do 5 ha. Celkem v mezidobí zaniklo 55 vodních ploch. Jejich zánik je spojen zejména s nerentabilitou chovu ryb, větším tlakem na zisk orné pưdy pro rozvíjející se zemědělství a počátky těžby uhlí ve východní části povodí $[1,5,9]$.

$\checkmark$ nižších částech území v širokých nivách a pahorkatinách se projevil také tlak na získávání orné půdy pro pěstování cukrové řepy, v letech 1848, 1851 a 1858 byly v Opavě postupně otevřeny tři cukrovary [13], další cukrovary byly provozovány v Háji ve Slezsku (1849) a Skrochovicích (1858). V tomto zájmovém území se v zemědělství projevovaly potřeby zajištění potravin pro rozvíjející se průmyslové aglomerace ve Slezsku a na Ostravsku, zájem o zemědělské pozemky byl způsoben i změnou ve způsobu hospodaření (přechod z trojpolního hospodaření na střídavý) a zrušením poddanství v roce 1848 [14]. Zachovány byly především rybníky, které měly kromě rybochovné funkce i funkci vodohospodářskou, např. jako retenční nádrž pro vodní mlýny, pily, hamry a další vodohospodářské objekty, případně byly využity pro průmysl. Příkladem je rybník u Dolních Životic s vodním mlýnem na řece Hvozdnice, rybník u Horních Životic s vodním mlýnem na Heřmanickém potoce. Větši výskyt dochovaných rybníků byl $\vee$ polovině 19. století evidován u méně vydatných toků $v$ zemědělských krajinách v oblasti pahorkatin a rovin, kde byla nutnost tyto vodní plochy pro pohon vodního kola zachovat [1].

Většinou byly rybníky vypuštěny a prevedeny do orné půdy, prípadně luk a pastvin, u větších sídel se staly později součástí zastavěných ploch, včetně rozširujuících se průmyslových areálů. V letech 1876-1880 bylo v povodí Opavy pouze 65 vodních ploch o celkové výměře 134 ha. Za zmínku stojí i velikostní struktura vodních ploch $v$ tomto období, nebyla evidována ani jedna vodní plocha s výměrou větší než 10 ha, pouze jedna vodní plocha s výměrou od 5 do 10 ha. Od roku 1953-1957 do současnosti se výrazně zvýšil počet vodních ploch v povodí Opavy, přičemž nárůst byl zaznamenán ve všech velikostních kategoriích. Na výrazném navýšení celkové výměry vodních ploch však měla od poloviny 20. století hlavní podíl nově budovaná vodní díla Kružberk (240 ha) a Slezská Harta (840 ha) a taktéž obnova některých velkých rybničních soustav - např. v okolí Hlučína a Dolního Benešova. V současnosti je celková výměra vodních ploch v povodí Opavy přibližně 1750 ha, přičemž 60 \% z nich je tvořeno velkými vodními nádržemi (tabulka 1).

Při hodnocení potenciálu obnovy vodních ploch v povodí Opavy z let 1736-1768 bylo zjištěno, že ze 148 vodních ploch se 44 dochovalo do současnosti a 104 zaniklo. Velký potenciál pro obnovu má 12 lokalit, na kterých je patrná velká část hráze, 10 lokalit s dochovanou hrází se zpevněnou komunikací a 5 lokalit s hrází s nezpevněnou komunikací. Obtížněji jsou obnovitelné vodní plochy, u nichž je dochována jen menší část hráze (8) nebo stopy po hrázi (17). U 52 bývalých vodních ploch nejsou žádné stopy hráze $v$ současnosti v terénu patrné, i přesto, v prípadě zájmu a aktivit majitelů pozemků, může být v daném území některá vodní plocha se zcela novou hrází obnovena.

\section{Povodí Jevišovky}

V prvním sledovaném období (1763-1768) bylo v povodí Jevišovky identifikováno celkem 217 vodních ploch, při rekonstrukci zákresu větších vodních ploch z map 1. rakouského vojenského mapování bylo zakresleno více než 1050 ha vodních ploch (tabulka 2). I když jde jen o orientační údaj, Ize konstatovat, že v letech 1763-1768 bylo ze všech sledovaných období v tomto povodí dosaženo největší celkové rozlohy vodních ploch. Největší zaniklé vodní plochy se nachází $\checkmark$ dolní části toku Jevišovka mezi Lechovicemi a Hrušovany nad Jevišovkou, tedy v krajině rovin a širokých říčních niv [12]. Ukázky zaniklých rybníků mezi obcemi Božice a Pravčice jsou zaznamenány na obr. 2-4. Interpretací zákresu z mapy 1. rakouského vojenského mapování s využitím detailního podrobného modelu území byly provedeny zákresy rybníků v GIS a spočtena jejich přibližná výměra - na obr. 2 zleva doprava: Fostitzer Teich (107 ha), Erdberger Teich (153 ha), Johanner Teich (86 ha). Velikostní kategorie nebyly vzhledem k nepřesnostem zákresu na mapách 1. vojenského mapování sledovány.

$\checkmark$ letech 1836-1852 pokles počet vodních ploch na 104, přesto celková výměra vodních ploch v povodí Jevišovky byla stále poměrně vysoká (615 ha). Je to dáno i největším zastoupením velkých vodních ploch o výměře větší než 10 ha (celkem 13 vodních ploch). V letech 1876-1880 bylo v povodí Jevišovky pouze 65 vodních ploch o celkové výměre 134 ha (tabulka 2). Za zánikem vodních ploch v tomto období stojí různé hybné síly, např. pokles poptávky po rybím mase, obecné změny ve způsobu zemědělského hospodaření, rozvoj cukrovarnictví, rozvoj lihovarnictví, rozvoj pěstování technických plodin pro průmysl $[1,5,9]$. Na největších zaniklých rybnících hospodařili predevším majitelé velkostatků $v$ okolí Hrušovan nad Jevišovkou, konkrétně na dvorech Nový Dvůr, Karlov, v lokalitě dnešní Kolonie u dvora. Velkostatkáři se zabývali

Tabulka 2. Počet a rozloha vodnich ploch v povodí Jevišovky v letech 1763-2015

Table 2. Number and area of water bodies in Jevišovka river basin (1763-2015)

\begin{tabular}{|c|c|c|c|c|c|c|}
\hline & do 1,0 ha & $1,0-4,9$ ha & $5,0-9,9$ ha & 10,0 ha a více & Počet celkem & Výměra celkem (ha) \\
\hline $1763-1768$ & & & & & 217 & 1053,1 \\
\hline $1836-1852$ & 44 & 38 & 9 & 13 & 104 & 614,9 \\
\hline $1876-1880$ & 28 & 29 & 6 & 2 & 65 & 134,3 \\
\hline 1953-1957 & 90 & 25 & 2 & 3 & 120 & 165,6 \\
\hline 1988-1995 & 130 & 49 & 8 & 7 & 194 & 357,7 \\
\hline 2002-2006 & 167 & 53 & 13 & 5 & 238 & 379,1 \\
\hline 2014-2015 & 215 & 54 & 13 & 6 & 288 & 405,8 \\
\hline
\end{tabular}




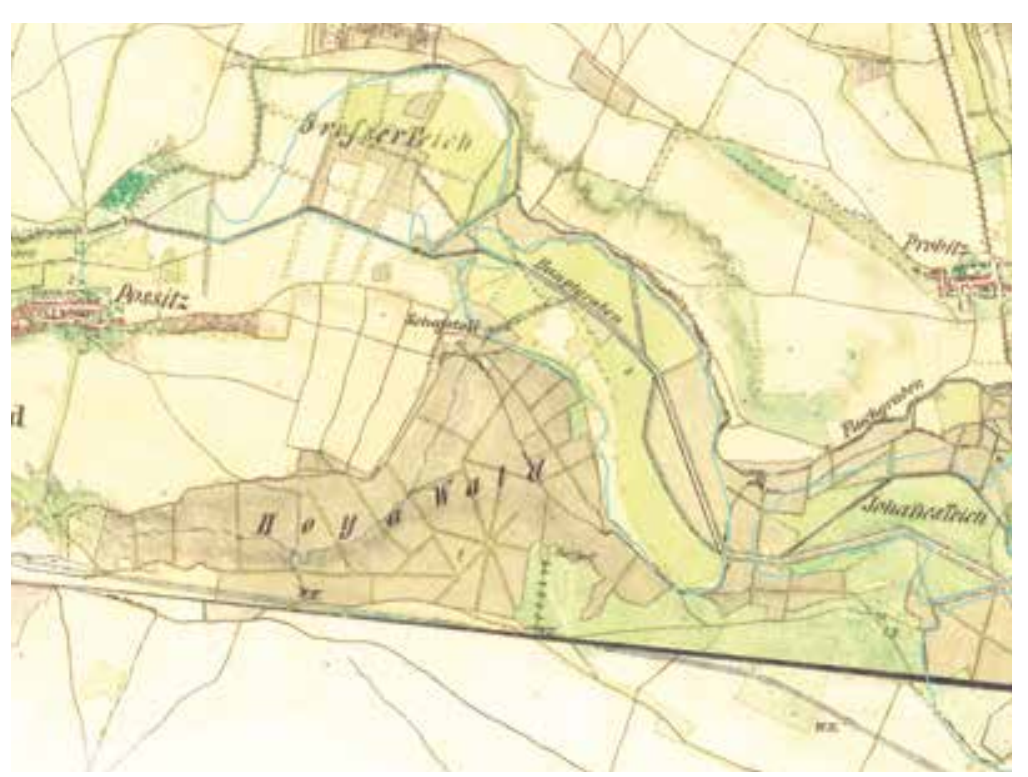

Obr. 3. Zaniklé rybníky v povodí Jevišovky u obcí Božice a Pravice (1841) (zdroj: VÚKOZ, v. v. i., ${ }^{\text {st }}$ Military Survey, Austrian State Archive/Military Archive, Vienna, Laboratoř geoinformatiky Univerzita J. E. Purkyně)

Fig. 3. Ponds in Jevišovka river basin near the villages Božice and Pravice (1841) (source: RILOG, p.r.i., $1^{\text {st }}$ Military Survey, Austrian State Archive/Military Archive, Vienna, Laboratory of Geoinformatics University of J. E. Purkyně)

v 19. století především pěstováním technických plodin pro lihovarnictví, textilní průmysl, potravináŕský průmysl a po vzniku cukrovarů v regionu v Hrušovanech nad Jevišovkou (1850), Želeticích (1870) i pro cukrovarnický průmysl [13]. Většinou byly rybníky vypuštěny a převedeny do orné půdy, případně luk a pastvin [7-9]. Dochované rybníky se v polovině 19 . století vyskytovaly především v horní části povodí Jevišovky v krajině vrchovin a členitějších pahorkatin, část z nich sloužila pro rybochovné účely, některé pro provoz vodních mlýnů a pil (např. u Jackova a Krnčic).

V letech 1953-1957 byla celková výměra vodních ploch v povodí Jevišovky stále velmi nízká (okolo 166 ha), přičemž narostl počet vodních ploch, především však s menší rozlohou. V druhé polovině 20. století dochází k budování větších vodních nádrží, retenčních nádrží a na počátku 21. století k zakládání malých vodních nádrží a realizaci protipovodňových opatření. To se projevilo jak nárůstem počtu vodních ploch, tak i postupným růstem celkové výměry vodních ploch v povodí Jevišovky. Přesto není stále dosaženo hodnot celkových výměr z poloviny 19. století či poloviny 18. století (tabulka 2).

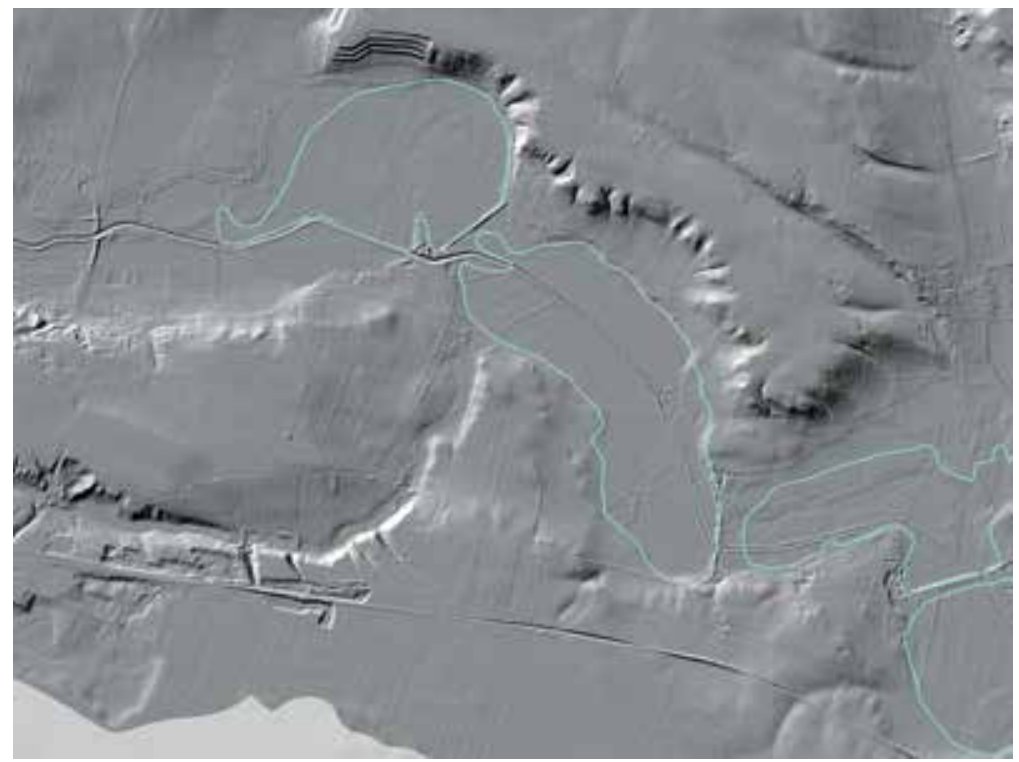

Obr. 4. Hráze zaniklých rybníků na digitálním modelu reliéfu České republiky 4. generace (DMR 4G) (zdroj: ČÚZK)

Fig. 4. Dams of extinct ponds on the digital terrain model of the Czech Republic $4^{\text {th }}$ generation (source: ČÚZK)

Při hodnocení potenciálu obnovy vodních ploch v povodí Jevišovky z let 1736-1768 bylo evidováno 78 vodních ploch z celkových 210, které se dochovaly až do současnosti. Celkem 132 vodních ploch zaniklo a dosud nebylo obnoveno. Největši potenciál pro obnovu má 24 lokalit, na kterých je patrná velká část hráze, 26 lokalit s dochovanou hrází se zpevněnou komunikací a 17 lokalit s hrází s nezpevněnou komunikací (obr. 5). Celkem je tedy v dobrém stavu dochována hráz u 51 \% zaniklých vodních ploch v povodí Jevišovky. Menší potenciál pro obnovu mají bývalé vodní plochy, u nichž je dochována jen menší část hráze (10) nebo stopy po hrázi (22). U 33 bývalých vodních ploch v povodí Jevišovky z období let 1763-1768 nejsou v současnosti patrné žádné stopy hráze, přesto je možné v některých lokalitách ještě vodní plochu obnovit.

\section{Povodí Bystřice}

V prvním sledovaném období (1763-1768) bylo v povodí Bystřice evidováno celkem 233 vodních ploch, prii rekonstrukci zákresu větších vodních ploch z map 1. rakouského vojenského mapování bylo zakresleno více než 890 ha vodních

Tabulka 3. Počet a rozloha vodních ploch v povodí Bystřice v letech 1763-2015 Table 3. Number and area of water bodies in Bystřice river basin (1763-2015)

\begin{tabular}{|c|c|c|c|c|c|c|}
\hline & do 1,0 ha & $1,0-4,9$ ha & 5,0-9,9 ha & 10,0 ha a více & Počet celkem & Výměra celkem (ha) \\
\hline $1763-1768$ & & & & & 233 & 893,3 \\
\hline $1836-1852$ & 96 & 33 & 4 & 9 & 142 & 658,1 \\
\hline $1876-1880$ & 110 & 23 & 4 & 3 & 140 & 209,6 \\
\hline 1953-1957 & 124 & 17 & 3 & 1 & 145 & 118,8 \\
\hline $1988-1990$ & 174 & 31 & 5 & 5 & 215 & 236,6 \\
\hline $2002-2006$ & 303 & 32 & 3 & 8 & 346 & 281,2 \\
\hline $2014-2015$ & 349 & 34 & 8 & 9 & 400 & 340,8 \\
\hline
\end{tabular}




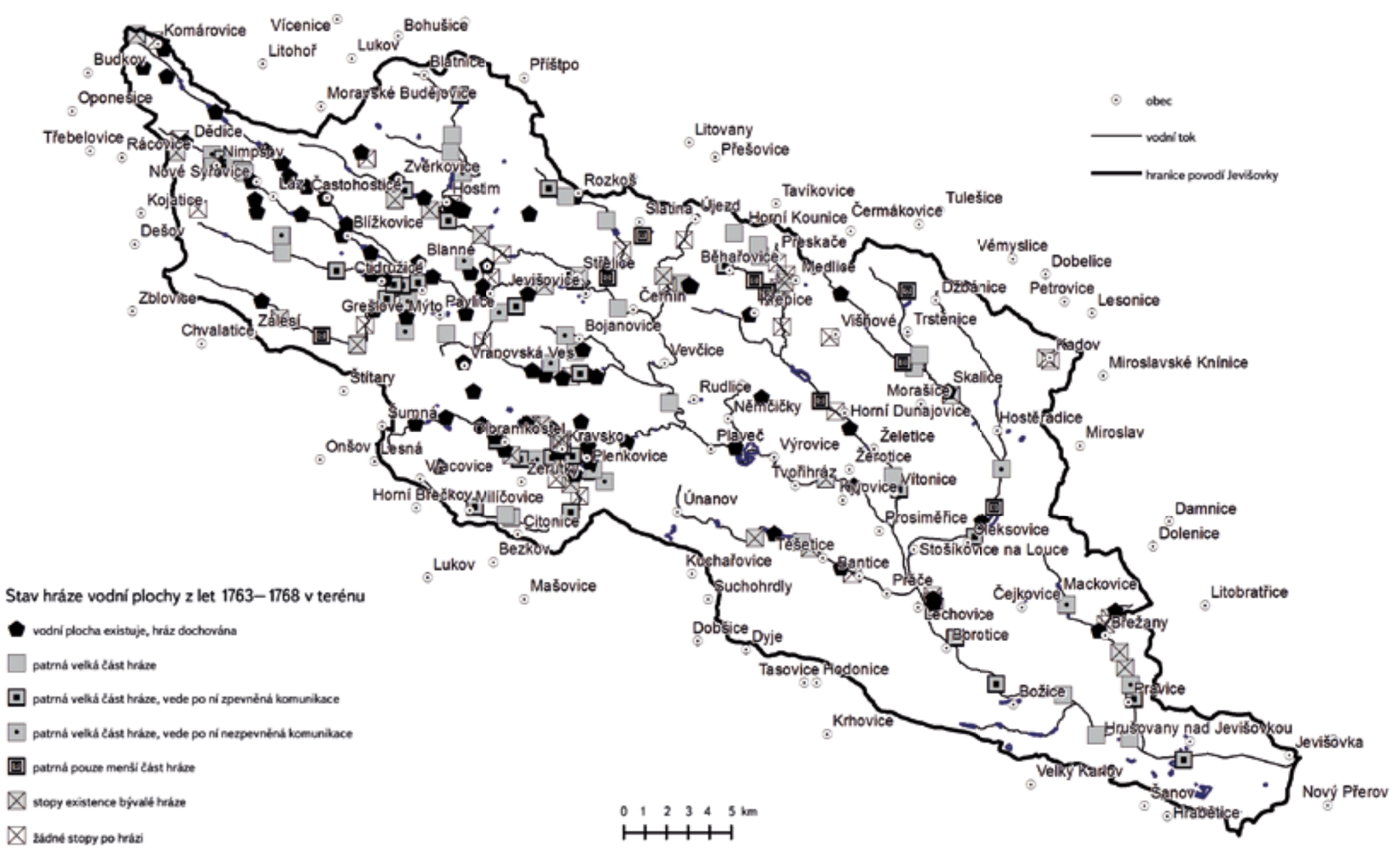

Obr. 5. Stav hrází vodních ploch z let 1763-1768 v povodí Jevišovky

Fig. 5. Condition of dams of water areas from 1763-1768 in the Jevišovka river basin

ploch (tabulka 3). I když jde jen o orientační údaj, Ize konstatovat, že v letech 1763-1768 bylo ze všech sledovaných období v tomto povodí dosaženo největší celkové rozlohy. Největší zaniklé vodní plochy se nachází v dolní části toku Bystř̌ice v okolí Chlumce nad Cidlinou a ve střední části povodí severně od Nechanic. Velikostní kategorie nebyly vzhledem k nepřesnostem zákresu na mapách 1. vojenského mapování sledovány.

$\checkmark$ letech 1836-1852 poklesl počet vodních ploch na 142 (tabulka 3), přesto celková výměra vodních ploch v povodí Bystřice byla stále poměrně vysoká (658 ha). Je to dáno i poměrně velkým zastoupením velkých vodních ploch o výměře větší než 10 ha (celkem devět vodních ploch), především však dochováním čtyř významných rybníků v rybniční soustavě v okolí Chlumce nad Cidlinou o výměrách 190 ha, 101 ha, 88 ha a 73 ha. Dochovány tak zůstaly prédevším velké rybochovné rybníky z krajin širokých říčních niv a rybničních krajin. V letech 1876-1880 bylo v povodí Bystřrice přibližně stejné množství vodních ploch, ovšem tři největší rybníky z předchozího období byly vysušeny, a to se projevilo na zásadním úbytku celkové rozlohy vodních ploch na 210 ha. Za zánikem vodních ploch v tomto období stojí různé hybné síly, např. pokles poptávky po rybím mase, obecné změny ve způsobu zemědělského hospodaření, rozvoj cukrovarnictví, rozvoj lihovarnictví, rozvoj pěstování technických plodin pro průmysl [1,5]. V povodí Bystřice byl významný úbytek vodních ploch $v$ druhé polovině 19. století spojen především s rozvojem cukrovarnictví, v zájmovém území vzniklo postupně šest cukrovarů: Chlumec nad Cidlinou (1838, 1840), Syrovátka (1848), Třebovětice (1851), Sadová (1862), Bašnice (1871), dalši cukrovary vznikly v bezprostředním okolí [13]. Většinou byly rybníky vypuštěny a převedeny do orné půdy, jako $v$ prípadě zisku půdy pro výsadbu cukrové řepy, dalších technických plodin, či obilovin pro výrobu potravin, prípadně byly převedeny do luk a pastvin, využívaných pro živočišnou výrobu [7-9]. V letech 1953-1957 pokračoval pokles celkové rozlohy vodních ploch až na minimum (okolo 119 ha), přičemž byl zaznamenán paradoxně mírný nárůst počtu vodních ploch, především však s menší rozlohou. V druhé polovině 20. století dochází k obnově některých rybníků, budování retenčních nádrží a na počátku 21. století k zakládání malých vodních nádrží a realizaci protipovodňových opatření. To se projevilo jak nárůstem počtu vodních ploch, tak i postupným růstem celkové výměry vodních ploch $v$ povodí Jevišovky. Přesto není stále dosaženo hodnot celkových výměr z poloviny 19. století či poloviny 18. století (tabulka 3).

Potenciál obnovy vodních ploch v povodí Bystřice z let 1736-1768 je obdobný jako u povodí Opavy, největší potenciál pro obnovu má 10 lokalit, na kterých je patrná velká část hráze, 16 lokalit s dochovanou hrází se zpevněnou komunikací a 15 lokalit s hrází s nezpevněnou komunikací. Jde o přibližně 24 \% ze zaniklých vodních ploch v povodí. Z celkových 233 vodních ploch evidovaných na mapách z let 1736-1768 se do současnosti dochovalo 68 vodních ploch a 165 jich zaniklo a dosud nebylo obnoveno. Menší potenciál pro obnovu vykazují bývalé vodní plochy, u nichž je dochována jen menší část hráze (8) nebo stopy po hrázi (36). Celkem 80 bývalých vodních ploch z povodí Bystřice z období let 1763-1768 nenese v současnosti žádné stopy hráze, i u nich ale je možná případná obnova vodních ploch za podmínky vybudování zcela nové hráze. 


\section{Aktuální využití zaniklých vodních ploch z období roku 1763-1768}

Další analýzy byly zaměřeny na hodnocení aktuálního převažujícího využití krajiny v zátopových oblastech vodních ploch z let 1763-1768, u kterých později došlo k jejich zániku, a nebyly dosud obnoveny. V povodí Bystřice zaniklo a dosud nebylo obnoveno 165 vodních ploch, v povodí Jevišovky 130 vodních ploch a v povodí Opavy 101 vodních ploch. Nejčastěji jsou zaniklé vodní plochy aktuálně využívány jako orná půda (obr. 6). V povodí Jevišovky jsou na druhém místě $v$ četnosti lokality aktuálně využivané jako les, v povodí Bystřice louky a v povodí Opavy zastavěné plochy (obr. 6). Obecně je zastoupení zastavěných ploch u zaniklých vodních ploch poměrně vysoké, jedná se o lokality, kde již není možné počítat $s$ jejich obnovou, stejně jako u rekreačních ploch. Naopak nejvyšší potenciál k obnově mají zaniklé vodní plochy na orné půdě a trvalých travních porostech, kde jsou z hlediska výstavby vodních děl očekávané nejmenší náklady a administrativní překážky. Obnova vodních ploch $\checkmark$ lesích a sadech je technicky a administrativně náročnější i s ohledem na funkci a význam dřevin v krajině.

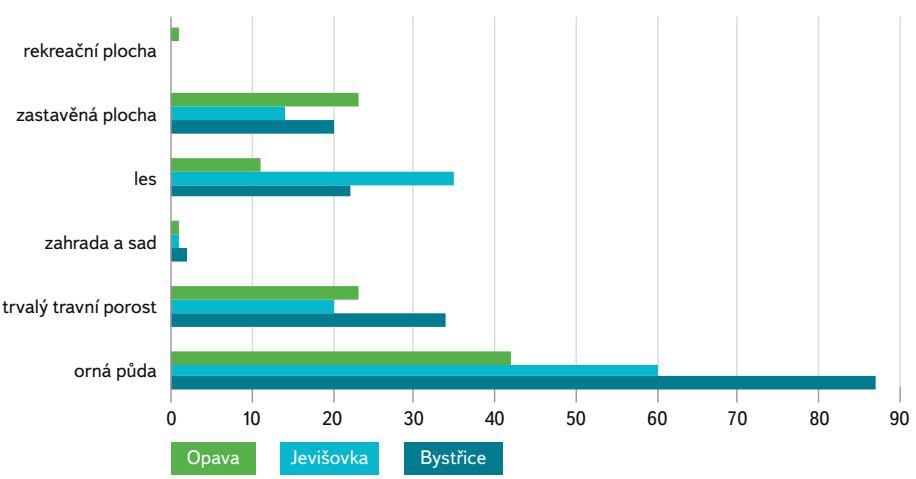

Obr. 6. Převažující aktuální využití krajiny na zaniklých vodních plochách z let 1763-1768 v zájmových územích

Fig. 6. The prevailing current land use on water areas extinct in the 1763-1768 in the study areas

\section{ZÁVĚR}

I přes nedostatečnou polohovou presnost je možné pro obnovu vodních ploch využít i staršího 1. rakouského vojenského mapování z let 1763-1768. Díky novým terénním modelům a interpretaci současných i starých topografických map prostředí GIS umožní lokalizaci hrází rybníků a zhodnocení možnosti obnovy vodních ploch v současnosti. Na základě analýz provedených na třech zájmových územích (povodí Opavy, Jevišovky, Bystř̌ice) Ize zhodnotit, že nejvyšší potenciál obnovy vodních ploch z let 1763-1768 je u povodí Jevišovky, kde má približně 51 \% zaniklých vodních ploch dochovanou hráz v pưvodním rozsahu. U ostatních dvou povodí je potenciál obnovy vodních ploch s využitím zachovalých starých hrází výrazně nižší - v povodí Opavy u 26 \% zaniklých vodních ploch, v povodí Bystřice u $24 \%$ zaniklých vodních ploch. U ostatních lokalit sice není dochován žádný pozůstatek pưvodní hráze, ale i přesto je tam možnost obnovy vodních ploch. $V$ povodí Bystřice zaniklo a dosud nebylo obnoveno 165 vodních ploch, v povodí Jevišovky 130 vodních ploch a v povodí Opavy 101 vodních ploch. Nejčastěji jsou zaniklé vodní plochy aktuálně využívány jako orná půda. Obecně jsou důležité zejména majetkové poměry v dané lokalitě, možnosti v rámci územního plánu, zájmy majitelů pozemků a prípadné limity území. Mapy jednotlivých hrází zaniklých vodních ploch Ize využít v územním a krajinném plánování, zejména při boji se suchem a kolísáním klimatu, při ochraně krajiny a managementu území.

\section{Poděkování}

Príspěvek byl zpracován s podporou projektu NAZV MZe ČR Č. QJ1620395 s názvem Obnova a výstavba rybníkư v lesních porostech jako součást udržitelného hospodarenís vodními zdroji v ČR.

Původní přispěvek byl publikován ve sborníku Rybníky 2018, ISBN 978-80-01-06452-8.

\section{Literatura}

[1] PAVELKOVÁ, R., FRAJER, J., NETOPIL, P. a kol. Historické rybníky České republiky: srovnání současnosti se stavem v2. polovině 19. století. Praha: Výzkumný ústav vodohospodárský T. G. Masaryka, 2014, 167 s.

[2] PAVELKOVÁ CHMELOVÁ, R., FRAJER, J., PAVKA, P., DZURÁKOVÁ, M., and ADÁMEK, P. Identification and Analysis of Areas of Historical Ponds on the Basis of Available Map Bases: Case Study of the Chrudimka River Basin. AUPO, Geographica, 2012, vol. 43, No. 2, p. 117-132.

[3] MÍKA, A. Nástin vývoje zemědělské výroby v českých zemích v epoše feudalismu. Praha: Státní pedagogické nakladatelství, 1960, 222 s.

[4] HAVLÍČEK, M., PAVELKOVÁ, R., FRAJER, J., and SKOKANOVÁ, H. The long-term development of water bodies in the context of land use: The case of the Kyjovka and Trkmanka River Basins (Czech Republic). Moravian Geographical Reports, 2014, vol. 22, No. 4, p. 39-50.

[5] HURT, R. Dějiny rybníkársství na Moravě a ve Slezsku, I. a ll. díl. Ostrava: Krajské nakladatelství v Ostravě, 1960.

[6] HAVLÍČEK, M., SKOKANOVÁ, H., DAVID, V., PAVELKOVÁ, R., NETOPIL, P. a ŠARAPATKA, B. Historicky vývoj vodních ploch ve vybraných povodích v České republice. In: David, V., Davidová, T. (eds) Rybníky 2016, sborník příspěvků odborné konference konané 23.-24. června 2016 na České zemědělské univerzitě v Praze. 2016. Praha: ČSKI, ČVUT, UPOL, VÚV, ČZU. p. 2-10.

[7] HAVLIČEK, M., KREJČ́KKOVÁ, B., CHUDINA, Z., and SVOBODA, J. Long-term land use development and changes in streams of the Kyjovka, Svratka and Velička river basins (Czech republic). Moravian Geographical Reports, 2012, vol. 20, No. 1, p. 28-42.

[8] HAVLIČEK, M., PAVELKOVÁ, R., FRAJER, J., and SKOKANOVÁ, H. The long-term development of water bodies in the context of land use: The case of the Kyjovka and Trkmanka River Basins (Czech Republic). Moravian Geographical Reports, 2014, vol. 22, No. 4, p. 39-50.

[9] PAVELKOVÁ, R., FRAJER, J., HAVLIČEK, M., NETOPIL, P., ROZKOŠNÝ, M., DAVID, V., DZURÁKOVÁ, M. and SARAPATKA, B. Historical ponds of the Czech Republic: an example of the interpretation of historic maps. Journal of Maps, 2016, vol. 12, No. 1, p. 551-559.

[10] FRAJER, J., KLADIVO, P., and GELETIČ, J. Reconstruction of extinct ponds using old maps, historical cadastres and the Digital Terrain Model of the Czech Republic of the 5th Generation. Acta Universitatis Palackianae Olomucensis, Facultas Rerum Naturalium, Geographica, 2013, vol. 44, No. 1, p. 59-69.

[11] DEMEK, J. a MACKOVČIN, P. (eds.) Hory a nižiny. Zeměpisnýlexikon ČR. 2. upravené vydání. Brno: AOPK ČR, 2006, $582 \mathrm{~s}$.

[12] LÖW, J. a NOVÁK, J. Typologické členění krajin České republiky. Urbanismus a územní rozvoj, 2008, roč. 11, č. 6, s. 19-23.

[13] GEBLER, J., MAREK, B. a FRONĚK, D. Cukrovarnický průmysl na území České republiky. Historický přehled - 220 let výroby cukru: 1787-2007. Listy cukrovarnické a repařské, 2007, roč. 123, č. 7-8, s. 252-258.

[14] GREŠLOVÁ, P., GINGRICH, S., KRAUSMANN, F., CHROMÝ, P., and JANČÁK, V. Social metabolism of Czech agriculture in the period 1830-2010. AUC Geographica, 2015, vol. 50, No. 1, p. 23-35. 
Autoři

Mgr. Marek Havlíček, Ph.D. ${ }^{1}$

凶marek.havlicek@vukoz.cz

Mgr. Hana Skokanová, Ph.D.'

凶hanka@skokan.net

Ing. Václav David, Ph.D. ${ }^{2}$

凶vaclav.david@fsv.cvut.cz

RNDr. Renata Pavelková, Ph.D. ${ }^{3}$

凶renata.pavelkova@upol.cz

RNDr. Aleš Létal, Ph.D. ${ }^{3}$

凶ales.letal@upol.cz

Mgr. Jindřich Frajer, Ph.D. ${ }^{3}$

凶jindrich.frajer@upol.cz

Mgr. Patrik Netopil, Ph.D. ${ }^{3}$

凶patrik.netopil@upol.cz

prof. Dr. Ing. Bořivoj Šarapatka, CSc. ${ }^{3}$

凶borivoj.sarapatka@upol.cz

'Výzkumný ústav Silva Taroucy pro krajinu a okrasné zahradnictví, v. v. i. 2České vysoké učení technické v Praze

${ }^{3}$ Univerzita Palackého v Olomouci

Příspěvek prošel lektorským řízením.
POSSIBILITIES OF USING OLD TOPOGRAPHIC MAPS FROM THE YEARS 1763-1768 FOR EVALUATING THE DEVELOPMENT OF WATER BODIES AND THE POTENTIAL FOR THEIR RENEWAL

HAVLICEK, M.'; SKOKANOVA, H.'; DAVID, V. ${ }^{2}$; PAVELKOVA, R. ${ }^{3}$; LETAL, A. ${ }^{3}$; FRAJER, J. ${ }^{3}$; NETOPIL, P. ${ }^{3}$; SARAPATKA, B. ${ }^{3}$

'The Silva Tarouca Research Institute for Landscape and Ornamental Gardening, p.r.i.

${ }^{2}$ The Czech Technical University in Prague

${ }^{3}$ The Palacký University Olomouc

Keywords: water reservoirs - old topographic maps river basin - Czech Republic

Potential of water areas restoration is a hot topic in present landscape planning. The focus is usually on water areas from mid-19 ${ }^{\text {th }}$ century where their location is quite good due to maps' positional accuracy. Yet, we can also use older Austrian military survey from 1763-1768, which enables us to locate dams of water areas and assess potential for restoration of these areas. Based on analysis of three study regions, we can say that the highest potential for restoration of water areas from 1763-1768 can be found in the river basin of the Jevišovka River. In this basin, approx. $51 \%$ of vanished water areas show preserved dam in its original range. The other two river basins show smaller potential for restoration of vanished water areas - it's $26 \%$ for river basin of the Opava River and $24 \%$ for river basin of the Bystřice River. In the Bystřice river basin 165 water areas have disappeared, in the Jevišovka river basin 130 water areas and 101 water areas in the Opava river basin. Most often, extinct water areas are currently used as arable land. In general, the property situation in the given locality, the possibilities within the territorial plan, the interests of the landowners and the possible limits of the area are important. Maps of individual dykes of dilapidated water areas can be used in landscape planning, especially in the fight against drought and climate fluctuations, landscape conservation and land management. 